\title{
Research Status and Development of Business Incubator in China
}

\author{
Xianmin Zhang1,2, Yang Xiao', Peijian $\mathrm{Wu}^{1}$ \\ ${ }^{1}$ School of Business Administration, Anhui University of Finance and Economics, Bengbu, China \\ ${ }^{2}$ University of Perpetual Help System Dalta, Pamplona Las Pinas City, Philippines \\ Email: zxm1256@qq.com
}

How to cite this paper: Zhang, X.M., Xiao, Y. and Wu, P.J. (2021) Research Status and Development of Business Incubator in China. Open Access Library Journal, 8: e8283. https://doi.org/10.4236/oalib.1108283

Received: December 9, 2021

Accepted: December 12, 2021

Published: December 15, 2021

Copyright $\odot 2021$ by author(s) and Open Access Library Inc.

This work is licensed under the Creative Commons Attribution International License (CC BY 4.0).

http://creativecommons.org/licenses/by/4.0/

\begin{abstract}
Business incubator plays an important role in cultivating the source enterprises of strategic emerging industries, building an innovation-oriented country, and forming an entrepreneurial upsurge driven by scientific and technological innovation in the whole society. Chinese scholars have conducted abundant academic research in the field of business incubator. Sorting out the research and development of business incubator will be beneficial to further research. This paper summarizes the literature on incubator research from 1999 to 2021 collected in Chinese Social Science Citation Index (CSSCI) database, and analyzes the research status of business incubator and the problems existing in the process of incubator construction and development. It is pointed out that the future construction of business incubator in China can be carried out from the construction of innovation environment, marketization and industrialization, and the promotion of talent mechanism and enterprise system.
\end{abstract}

\section{Subject Areas \\ Entrepreneurship}

\section{Keywords}

Business Incubator, Research Status, Construction and Development

\section{Introduction}

The world's first business incubator was born in 1959 in the United States. Incubator refers to an economic organization that provides facilities and services to selected incubated enterprises at a cost they can afford, adding value to them and helping them grow. It is one of the important consensuses in the post-war 
economic construction of various countries to strengthen the connection between industry, university and research by establishing science and technology incubators. The mission of incubators is to build and improve the service system of scientific and technological innovation and entrepreneurship, and improve the incubation capacity of regional scientific and technological enterprises. We will foster enterprises that are the source of strategic emerging industries, cultivate high-level and high-quality entrepreneurial teams, so as to create a favorable environment for scientific and technological innovation and entrepreneurship. Form an entrepreneurial climax driven by scientific and technological innovation in the whole society, and lay a solid foundation for transforming China's economic development mode and building an innovative country [1].

In 1987, China's first incubator-Wuhan East Lake New Technology Entrepreneur Center was born in Wuhan. In August 1988, The State Council included the construction of Chinese science and technology business incubator in the torch plan of the national science and technology industry development plan. After 30 years of development, China's science and technology business incubators have gradually expanded to Beijing, Shanghai, Tianjin and other parts of the country, ranking among the world's largest. Business incubators play an important role in helping start-ups survive, grow and develop, and are an important force in promoting regional innovation, entrepreneurship and economic development. With the rapid development of business incubator in practice, the role of fostering the growth of new enterprises has become increasingly prominent, and the theoretical circle has accumulated many valuable research results. Through literature review, Wang Xiaoqing et al. concluded that relevant researches mainly focused on service value and operation mode of business incubator, performance evaluation of incubators and incubators, incubation environment and incubation network, influencing factors, operation efficiency and development framework, etc. [2]. In the past, scholars mainly used the method of literature reading and induction to sort out the relevant research on business incubator, resulting in the overall grasp of business incubator research being still insufficient. To carry out comprehensive research, we should not only know the specific research content, but also grasp the research status, development trend and other information. Therefore, based on the Chinese Social Science Citation Index (CSSCI) database as the retrieval platform, and using word "incubator" as the term, this paper conducts a literature analysis on the identification and research priorities of business incubators in CSSCI database from 1999 to 2021. Conclusion and enlightenment are drawn from the study, which can be used for reference by researchers.

\section{Research Status}

\subsection{Overall Trend Analysis of Business Incubator Research}

The characteristics of business incubator research in different stages are closely related to China's economic development and policy environment. As shown in 
Figure 1, the overall number of business incubator research publications shows a trend of first increasing and then decreasing, which can be divided into four stages as a whole. The period from 1999 to 2005 belongs to the initial stage of research. Due to the lack of relevant theories and foundations, the number of papers published is relatively low, and the research in this field is in the preliminary discussion stage. From 2006 to 2009, influenced by the rapid economic development and guided by the national entrepreneurship policy, the number of scholars and institutions engaged in research in this field increased rapidly, and the growth rate was relatively fast, indicating that business incubator received the attention and attention of scholars, and the peak reached 40 papers in 2009. After 2009, the number of posts remained tepid for 5 years, and then gradually decreased. In 2016, the economic growth rate dropped to $6.7 \%$. In order to realize the transformation and upgrading of national economic development and accelerate the improvement of technological innovation level, the government encouraged mass entrepreneurship and innovation, and the number of research papers increased again in 2018 and 2019.

\subsection{Hot Spot of Business Incubator Research}

Based on the retrieved CSSCI research literature, literature induction method is adopted to sort out the following three research hotspots.

First, the operation mode and innovation of business incubator. As a new organizational form to help new enterprises grow, business incubator has developed its own characteristics and began to take on various forms. Jin Jialin et al. [3] put forward the development model of China's high-tech industry incubator according to the different stages and needs of the development cycle of high-tech enterprises and the characteristics and laws of China's high-tech industry development. Luo Feng [4] analyzed the unique business model of incubator in China from different positioning functions, and explored the logical structure and value creation mechanism of incubator business model. Zhang Yu et al. [5] studied the new generation of science and technology business incubators from the perspective of strategic alliance, and sorted out the evolution path of the development mode of China's science and technology business incubators. Lu Gang et al. [6] proposed the 4.0 mode of incubator development based on practical cases, discussed its new definition, new trend, new mode and new source, and put forward relevant suggestions to promote the 4.0 mode.

The second is the performance evaluation of business incubators and incubating enterprises. Yang Zhenning et al. [7] adopted exploratory factor analysis method to extract six factors to evaluate the performance of science parks: technological environment, cultural atmosphere, regional attraction, local government policy support, capital channels and market docking, and put forward a conceptual model to evaluate the performance of Science parks in China. Shao Jungang et al. [8] established the growth performance model of incubating enterprises based on contact, and analyzed the impact of frequent contact between the management of business incubator and employees of incubating enterprises 


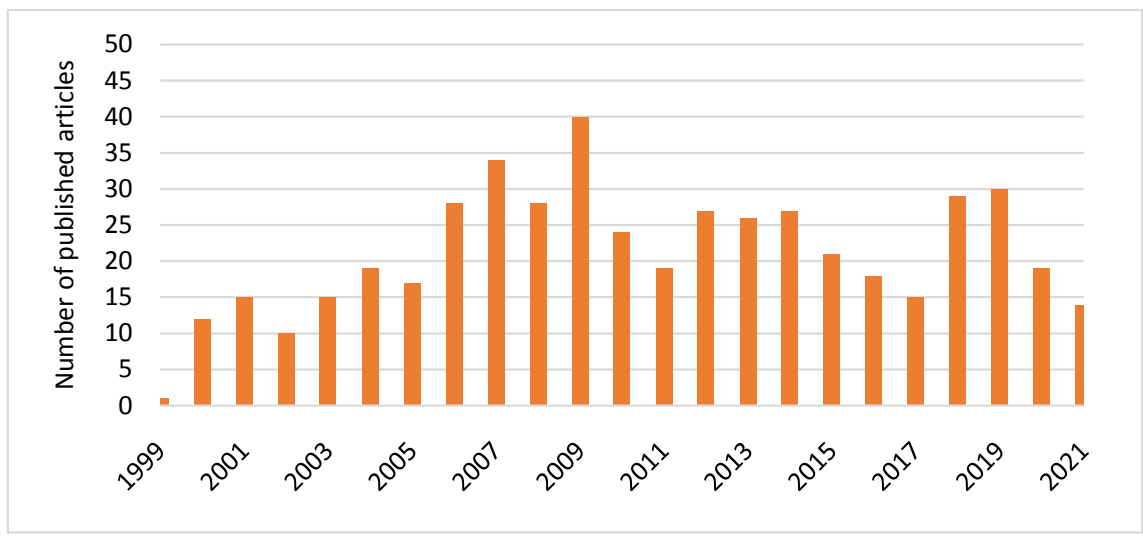

Figure 1. Temporal distribution of business incubator Publications (1999-2021).

on the growth performance of incubating enterprises. Xu Ke et al. [9] constructed a structural equation model of "entrepreneurial-innovation-driven enterprise performance" based on the research data of 256 incubated enterprises based on organizational strategy and value chain theory, and proposed the constructs of enterprise performance. These researches are of great significance for improving the operation effect of business incubator, promoting the development of incubated enterprises and promoting the growth performance of incubated enterprises.

Third, enterprise incubation environment and incubation network. Liu Xiaoying [10] defined the concept of virtual science and technology incubation network, and put forward the structural model of virtual science and technology incubation network and the expansion model from physical incubator to virtual science and technology incubation network. Su Jingqin et al. [11] analyzed the generation mode of high-tech incubation network from the perspective of dynamic evolution and proposed three-generation modes of high-tech incubation network: research institute derivative network, group enterprise derivative network and multi-agent joint network. Wang Zhaoqun et al. [12] explored the conceptual model of contract and trust in the incubation network, and verified the influence path of contracts of different dimensions on trust of different dimensions in the incubation network, as well as the moderating role of technological overlap in its process.

\section{Problems Existing in the Construction of Business Incubator}

According to previous research findings, although China's business incubator has made great progress, there are still many problems in the development process. For example, the development between regions is unbalanced, the incubation function is not perfect, the financing platform is lacking and the quality of personnel is low. There is still a lack of cooperation between incubators on resource sharing and complementary advantages. And the connections between incubators and incubators and between different enterprises within incubators 
are not close enough. These problems restrict the further development of incubators, but also have a negative impact on incubating enterprises, the system and mechanism innovation still need to be further explored.

\subsection{Regional Development Is Unbalanced}

Despite the rapid development of science and technology business incubators in China, the number of incubators varies greatly among different regions, different provinces and different cities. As shown in Table 1, in the list of national science and technology business incubators to be determined in 2020, Guangdong province, Jiangsu Province and Zhejiang province have the largest number of incubators, with 21,19 and 12 respectively. In the central provinces, hubei and Henan have more incubators. Among the southwest provinces, Sichuan and Chongqing have 6 and 3 incubators respectively. Most of the science and technology business incubators in China are concentrated in the eastern region and a few central cities, which has not formed a radiation effect facing the whole country, which greatly restricts the overall coordinated development of the incubator business in China.

Table 1. Distribution of newly added national science and technology business incubators in 2020 .

\begin{tabular}{|c|c|c|c|}
\hline Province & Amount & Province & Amount \\
\hline Guangdong & 21 & Heilongjiang & 2 \\
\hline Jiangsu & 19 & Hunan & 2 \\
\hline Zhejiang & 12 & Tianjin & 2 \\
\hline Hubei & 9 & Yunnan & 2 \\
\hline Hebei & 7 & Guizhou & 1 \\
\hline Anhui & 6 & Hainan & 1 \\
\hline Henan & 6 & Jilin & 1 \\
\hline Shanghai & 6 & Jiangxi & 1 \\
\hline Sichuan & 6 & Liaoning & 1 \\
\hline Beijing & 4 & Neimenggu & 1 \\
\hline Guangxi & 4 & Ningxia & 1 \\
\hline Shaanxi & 4 & Qinghai & 1 \\
\hline Fujian & 3 & Shanxi & 1 \\
\hline Shandong & 3 & Tibet & 1 \\
\hline Chongqing & 3 & Xinjiang & 1 \\
\hline Gansu & 2 & & \\
\hline
\end{tabular}

(Data source: Ministry of Science and Technology Torch Center). 


\subsection{The Financing Function Is Not Sound}

The existing business incubators in China are specially built by the government directly or indirectly with a large amount of funds. They have complete hardware facilities and low fees, and provide good basic service support for incubating enterprises. However, most business incubators are not able to provide comprehensive management services, except that very few business incubators provide comprehensive support for the specific operation of enterprises. The function of incubation period needs to be enhanced. In terms of creditor's rights financing, small and medium-sized enterprises are generally unable to provide tangible assets that can be pledged and guaranteed, the credit system has not been established and perfected, and banks need to avoid risks, etc., which makes it difficult for them to obtain creditor's rights financing from banks and other financial institutions. Most incubators in China are operated by the government, and the funds are financed by the finance. In addition, the development of venture capital lags behind, resulting in the development of China's incubator itself, causing a negative impact on incubating enterprises [13].

\subsection{The Talent System Is Not Perfect}

Many managers of the existing business incubators in China come from government agencies or public institutions, with insufficient service awareness and lack of entrepreneurial experience, operation and management ability, as well as high-level technical ability and technical support. Incubators also have a series of problems in human resources management, the structure and quality of incubator managers cannot meet the requirements of cultivating high-tech enterprises, the establishment of an effective human capital support platform to promote the long-term development of business incubators and technology enterprises in China is imperative [14]. This will directly affect the operation efficiency of the technology business incubator, and affect the service quality and level of the incubator.

\section{Business Incubator Construction Promotion Strategy}

Only when incubators really operate according to the law of market economy can they guide the enterprises to develop better in the market economy. With the development of socialist market economy and socialized service industry, business incubator will be further marketized and industrialized. In order to promote the development of Incubator industrialization in China, the following aspects must be improved:

\subsection{Innovate Environment Construction and Strengthen the Support of Incubators in Disadvantaged Areas}

Promoting the construction of business incubator is a response to the development of society and the trend of The Times. In order to solve the problem of insufficient understanding of business incubator, it is necessary to understand the 
growth rules and key needs of incubated enterprises in the growth stage. And to meet the needs of enterprises is a major problem related to the survival and development of enterprises, and is the basic content of the function optimization of professional incubator. Increase the support of local government, select appropriate incubator development mode, vigorously support and support incubator construction, strengthen incubator innovation environment construction.

\subsection{Accelerate the Marketization and Industrialization of Incubators, and Form a Self-Benign Development Mechanism}

The income structure of incubators has not fundamentally changed, and the profit model needs to be sublimated. Gradually marketization is the basic direction of incubator development, and the profit model of professional incubator should also be transformed into a process of capital operation and market development. With the government giving up the leading position, the progress of incubator's marketization operation gradually shows the problems caused by insufficient attention to operation efficiency and low income due to the income structure relying on property. Business incubators should innovate service modes, introduce social forces to provide services for incubators and incubated enterprises, and promote the socialization of incubation services. China's business incubator industry needs to open up upstream and downstream, and form a support system to help the development of small and medium-sized enterprises. Accelerate the downstream system development of incubator industry and establish accelerators.

\subsection{Improve the Talent Mechanism, Improve the Overall Service Level}

We will strengthen the talent strategy, intellectual property strategy and extensive partnership strategy. With the rapid development of professional incubators, it is urgent for a large number of high quality, experienced and professional talents to participate in the construction and management of incubators. At the same time, the cultivation standards and assessment standards of incubator management talents also need to be constantly innovated. Business incubators should give full play to their own advantages, and introduce professional services with the help of social institutions for service projects without their own advantages. It is necessary to explore the ways and methods of paid incubation service, and promote the service quality and efficiency of incubators through paid incubation service, so that incubated enterprises can get personalized incubation service with constantly improved level and quality.

\section{Conclusions}

China is a country with a vast territory and uneven development. There are great differences in economic development between eastern and western regions and different provinces. Business incubator originated in the United States, and its 
development in China must follow the background of China's social and economic development [13]. In the process of its development, there will inevitably be problems such as profitability, limited policy radiation, resource docking challenges and industry operation. So, the future development of business incubator should adhere to the construction of the distinctive and space, improve the business incubation service chain, strengthen policy perfecting and development level, reasonable integration of incubator resources, broaden the enterprise investment and financing channels, strengthen the construction of production system, achieve the coordinated development of science and technology incubators with other ones. In the future, China's business incubators will continue to develop towards the direction of market and government co-leading, industrial incubators emerging in batches, incubation mode changing constantly, incubator enterprise system promoting and so on, and finally form the network, virtualization and internationalization of incubators.

In addition, this research was supported by relevant research projects, which focused on analyzing the impact of team heterogeneity on business incubator graduation and the interaction of multi-dimensional heterogeneity. In order to reflect the complexity of entrepreneurship, we should study it from the perspective of overall configuration as much as possible. Enrich the theory of cultivation and construction of the incubator.

\section{Fund Project}

School-level scientific research project of Anhui University of Finance and Economics, behind the "butterfly" or "fall" of incubator enterprises-based on the research perspective of entrepreneurial team heterogeneity (No. ACKY1849).

\section{Conflicts of Interest}

The authors declare no conflicts of interest.

\section{References}

[1] Wang, L. (2014) Consensus or Boundary Concept: An Analysis of the Definition of "Incubator" in Academic Journals Based on Grounded Theory. Science of Science and Technology Management, 35, 146-153.

[2] Wang, X., Wu, Q. and Qin, X. (2020) Research Hotspot and Trend of Business Incubator in China-Knowledge Graph Analysis of CiteSpace. Journal of South China University of Technology (Social Science Edition), 22, 76-87

[3] Jin, J., Li, L. and Liu, X. (2004) Research on the Comparative Selection of high-tech Industry Incubator Model. Scientific Management Research, 22, 76-79.

[4] Luo, F. (2014) Value Creation Analysis of Business Model of Business Incubator. Management World, No. 8, 180-181.

[5] Zhang, Y., Mai, Q. and Duan, Q. (2015) Research on the Strategic Alliance and Operation Mechanism of the New Generation of Technology Business Incubator. Science and Technology Progress and Countermeasures, 32, 100-104.

[6] Lu, G., Du, L., Huang, Y., et al. (2017) Promoting the Development of 4.0 Model of 
Technology Business Incubator. Science and Technology Management Research, No. 17, 162-166.

[7] Yang, Z., Lu, P. and Wang, Y. (2007) Performance Evaluation of Science Parks in China: Based on the Perspective of Enterprise Demand. Studies in Science of Science, No. 5, 864-870.

[8] Shao, J., Chang, L. and Wang, W. (2009) An Empirical Study on the Relationship between Business Performance and Business Performance. Research and Development Management, No. 4, 91-96.

[9] $\mathrm{Xu}, \mathrm{K} .$, Yao, F., Sun, T., et al. (2018) Innovation Driving Process from Entrepreneurial Orientation to Enterprise Performance. Studies in Science of Science, 36, 176-182.

[10] Liu, X. (2007) Research on Virtual Technology Incubation Network. China Soft Science, No. 11, 11-18.

[11] Su, J., Zhou, Y. and Hong, Y. (2011) Research on the Development of High-Tech Incubation Network. Science of Science and Management of Science and Technology, No. 12, 45-52.

[12] Wang, Z., Hu, H., Li, H., et al. (2018) Research on the Relationship between Trust and Contract in Incubation Networks. Studies in Science of Science, 36, 714-722.

[13] Zhang, J. (2011) Research on the Status Quo and Trend of Incubator Development in the World and China. Market Weekly(Theoretical Research), No. 6, 132-133+74.

[14] Du, L. and Wei, B. (2010) Construction of Human Capital Support Platform for Business Incubator. Industry and Technology Forum, 9, 17-19. 